Man and Nature

L'homme et la nature

\title{
The Magic Flute and Viennese Opinion
}

\section{Jay MacPherson}

Volume 6, 1987

URI : https://id.erudit.org/iderudit/1011876ar

DOI : https://doi.org/10.7202/1011876ar

Aller au sommaire du numéro

Éditeur(s)

Canadian Society for Eighteenth-Century Studies / Société canadienne d'étude du dix-huitième siècle

ISSN

0824-3298 (imprimé)

1927-8810 (numérique)

Découvrir la revue

Citer cet article

MacPherson, J. (1987). The Magic Flute and Viennese Opinion. Man and Nature/ L'homme et la nature, 6, 161-172. https://doi.org/10.7202/1011876ar

Copyright (C Canadian Society for Eighteenth-Century Studies / Sociéte canadienne d'étude du dix-huitième siècle, 1987
Ce document est protégé par la loi sur le droit d'auteur. L'utilisation des services d'Érudit (y compris la reproduction) est assujettie à sa politique d'utilisation que vous pouvez consulter en ligne.

https://apropos.erudit.org/fr/usagers/politique-dutilisation/ 


\section{THE MAGIC FLUTE AND VIENNESE OPINION}

It is clearly the case that downright fantastic interpretations, tottering on dubious bases, find far more adherents than those not engendered on airy heights but established on foundations of real fact. ${ }^{1}$

The notion that the text of The Magic Flute contains a political allegory commences in 1794, three years after its first production, in various pamphlets and articles. It was incorporated into book-length critical works on Mozart in the mid-nineteenth century, and has had a sort of folklore persistence down to the present: witness Jonathan Miller's production for Scottish Opera in January $1983,{ }^{2}$ in which the Queen of the Night is Maria Theresia, surrounded by a priestly-looking set of councillors; Sarastro and the initiates are Ignaz von Born, the learned Master of the Viennese lodge True Concord, and his fellow-Masons (Born sung by Canadian bass Don Garrard who even looked like him); and the finale is a celebration of the early stages of the French Revolution, with revolutionary wenches kicking up their knees and tricolor flags being joyously unfurled. In this reading the conflict of darkness and light is that between an autocratic and priest-ridden old régime, embodied with due caution in a monarch who died eleven years before the opera's first production in 1791, and the forces of reason and democracy, represented by the Masons with their book-lined hall that remains in the background of all the sets and by everyone's joining at the end to hail the progress of the Revolution. 
The Jacobin reading starts out in printed form in a Mannheim periodical of 1794, during the year or so when Mannheim like other cities on the west bank of the Rhine was in the hands of the French: the writer praises Mozart and Schikaneder, the author of the libretto, for their bold stroke of propaganda for the cause of the Revolution. A second political reading, of opposite tendency, formed part of a volume of the same year, Dialogues of the Gods against the Jacobins, anonymous but known to be the work of Joseph Valentin Eybel, a Viennese professor of canon law who was excommunicated and dismissed in 1779 because of his opposition to the Church's domination of secular concerns, especially education. Forced to spend the rest of his life in minor posts distant from Vienna, like many others in the decade following the French Revolution he became quite reactionary, in line with the shifts that saw most of the Emperor Joseph's reforms of the 1780s retracted before his death.

Eybel writes:

The Night, that is the Jacobin philosophy, bore a daughter, namely the Republic, whom she wanted to raise in the realm of Night and intended for a Jacobin marriage ... But under the protection of God, the Creator of Nature and Reason, and through the divine wisdom, matters were so arranged that the Republic was suddenly snatched away from her mother, the Night, and brought to safety in a place where there were still temples and priests ... and protected there by a mighty Power until, when the Night is driven away, she can cease to be a mere Republic and change her condition by marriage to a royal Prince who passes all tests and thereby proves himself a son of the true Light and a legitimate wooer.

Papageno, incidentally, is the "Jacobin bird-catcher who entices the people into the Jacobin clubs, locks them in the National cage, and so delivers them to the Night".

The Flute libretto is again read as a pro-Jacobin document in an anonymous pamphlet titled Secret History of the Jacobins in the Austrian States, London 1795 -- for "London" read reactionary Vienna under the autocratic and timorous Franz II -- proclaiming the existence of a vast network of Jacobin clubs established from before 1789 throughout Europe and in close touch with Paris, making converts and spreading propaganda, and, this writer insists, filling the theatres with allegories understandable only to the instructed: it was this secret meaning that, combined with the winning music of the entirely innocent Mozart, packed the Theater auf der Wieden two hours before starting-time every night for the first fortnight -- a rather absurd argument. At length, 
he says, some identifications came to be understood by the general public:

$\begin{array}{ll}\begin{array}{l}\text { The Queen of the Night ... } \\ \text { Pamina ... }\end{array} & \begin{array}{l}\text { the ancien régime } \\ \text { freedom, always the daughter of } \\ \text { despotism } \\ \text { the people }\end{array} \\ \begin{array}{ll}\text { Tamino ... } \\ \text { The Queen of the Night's three }\end{array} \\ \begin{array}{ll}\text { ladies ... } & \text { the deputies of the three estates } \\ \text { Sarastro ... } & \text { the wisdom of a better legislation } \\ \text { The initiates ... } & \text { the National Assembly } \\ \text { The Moor Monostatos .... } & \text { the emigrés } \\ \text { Papageno ... } & \text { the rich }\end{array}\end{array}$

This last is the most surprising; but it's explained that the rich, despised by the nobility and the Church, at first were glad to lend their influence to a change of régime, but as matters proceeded were unwilling to sacrifice any of their enjoyments to it: Papageno's feathers show his vanity, his panpipes show his lack of cultivation, and the sound of the glockenspiel that compels everyone to dance to its tune represents the clinking of gold.

This account is likely written by -- is certainly much of a piece with the writings of -- a man notorious in Vienna in the 90s for his defection from the ranks of the young liberals and reformists who had flourished in the 80s under Maria Theresia's son Kaiser Joseph II, who came to the throne determined to speed up his mother's program of reforms. One of Joseph's first moves, a loosening of the hitherto tight and Church-controlled censorship, allowed the circulation of foreign books and, still more important, the rapid development of the voluminous pamphlet press that for a few years was to foster a lively public opinion among a city populace whose interests hitherto had stopped at entertainment and food. Leopold Alois Hoffmann, arriving in Vienna in 1782, was taken up by the liberal circle and first made a Freemason, though under age and unable to pay the initiation fees, and then, though himself without a university education, appointed to a professorship in Hungary. One of his last acts before leaving Vienna was late in 1784 as secretary of the lodge "Beneficence" to enter the name of Mozart as a candidate for initiation. By the time he returned to Vienna in 1790, Hoffmann had become an extreme conservative, first publishing a group of pamphlets demanding reforms in Freemasonry just after Kaiser Joseph had begun on one; then starting a periodical dedicated to alarmism, denunciation, and conspiracy-hunt- 
ing, and pressing on Joseph's short-lived successor Leopold lists of supposed Illuminati, dangerous by definition; then after Leopold's death and his own fall from favour drafting hysterical appeals to Kaiser Franz and the public at large to the effect that he was the only man who could spy out the dangers threatening the State. In the words of a critic, ${ }^{3}$ Hoffmann and his like are asking us to believe that two "truly superhuman men", meaning Weishaupt and Knigge, the former heads of the Illuminati, have

worked for the last decade upon the implementation of a plan which the tongue of men and of angels dare not utter, and the mind of men cannot comprehend. The most heterogeneous men, things, and events are all seen as machines in the hands of these two beings: the Allgemeine teutsche Bibliothek; the Literaturzeitung in Jena; a few hundred scholars who in fact frequently do not know one another; a few hundred court marshals, ambassadors, yes even princes; the Magic Flute, the armies in the Champagne; the generals of the coalition; the dysentery which caused the Prussians so much trouble [on retreat from Valmy]; the Duke of Orléans; the Temple of Reason in Paris; the Marseillaise; the bookseller Vollmer at Erfurt; Mirabeau, Sieyès, Robespierre, Cagliostro etc.

Fortunately the Vienna authorities were not easily disturbed by reports of the sedition spread by popular stage-shows, and Flute productions continued unhindered. So did interpretations, among which I should still mention that of Ludwig von Batzko, a Catholic fellow-townsman of Kant in East Prussia who published in 1794 a reading that is still allegorical, but at least much closer in its terms to those used in or close to Mozart's circle. The struggle of light and darkness waged over Pamina is that of Sarastro/Reason that wants to protect and foster the Enlightenment and the Queen of the Night/Superstition that wants to get control of it, in alliance with Monostatos/the Passions that have rebelled against Reason. "When the mighty of the earth [Tamino] are in indissoluble league with the Enlightenment, then is the victory of Reason assured; then rings out the triumph-song of the virtuous and wise." Batzko mentions that many scenes have some reference to Freemasonry, but assumes that most people who are not Masons will know enough about the ancient mystery-religions, very much an interest of the day, to grasp what they need to. No other writer, Viennese or other, makes any specific connection between The Magic Flute and Freemasonry for the next sixty-years -- though we should perhaps note the five-pointed star, a Masonic symbol, placed conspiculously in the frontispiece of the 1791 published libretto. ${ }^{4}$ 
Making Freemasonry the central interest of The Magic Flute was the concern of a number of interpreters in the mid-nineteenth century. Leopold Sonnleithner in 1857 wrote a paper that influenced Mozart's biographer Otto Jahn in which he claimed, not from any surviving tradition but evidently quite speculatively, that the apparent change of direction after the first few scenes, where the Queen of the Night and Sarastro reverse their respective moral status, results from the introduction of a new element into the plan, "the glorification of the Masonic Order"; it is Jahn who then extends this theme by discovering Masonic motifs in the music. Such motifs in the text were explored in detail by Georg Friedrich Daumer in an essay of 1861: besides lining up uses of the number three and references to the northern gate and to the trinity of strength, beauty, and wisdom, and so forth, he like Batzko saw a version of the historical struggle between Enlightenment and Counter-Enlightenment, the former represented by Sarastro as a kind of idealized lodge-master expressing the secular spirit of Masonry, the latter by the Queen of the Night as a personification of religion, attended by her three ladies who stand either for Judaism, Mohammedanism and Christianity or for the Catholic, Lutheran and Calvinist confessions; her cohort Monostatos, with his blackness and the hint of celibacy in his name, caricatures the Catholic priesthood.

Jonathan Miller's reading of the Flute appears to go back to a third midcentury commentator, Moritz Alexander Zille, in an essay of 1865, written after hearing The Magic Flute when he had recently become a Mason and was interested in Masonic history; his impressions led him to claim first, like the author of the Mannheim notice of 1794, that Mozart and Schikaneder had performed a bold action in bringing to the stage a defence of a cause disapproved of by the authorities in 1791; second, that the work is a kind of conscious swansong of Austrian Freemasonry -- which indeed sank from sight a year of two after, and did not fully recover from official repression until after World War I, some fifteen years before it vanished again under Hitler: Zille's own lodge was not in Vienna but in Leipzig.

Zille proceeds to state, still merely out of intuitive conviction, that Sarastro represents Ignaz von Born, the widely-honoured scientist who was the Master of Vienna's most distinguished lodge True Concord, and that further the Magic Flute's portrayal of Masonry had been developed under Born's direct instruction. Next, the Queen of the Night represents Maria Theresia, who hated and distrusted Masonry and who, just as the Queen and her ladies invade the lower regions of Sarastro's temple, once invaded a meeting of her husband's lodge (this story, and what it implies about her consort's Masonic activities, is pure 
legend); like Daumer, Zille sees Monostatos as the Catholic clergy. Tamino is Kaiser Joseph, Maria Theresia's son, not himself a Mason but liking to be called the protector of Masonry, and his destined bride Pamina is the Austrian people, waiting and sighing for Englightenment; Papageno and his bride are the populace, made happy with more concrete enjoyments. -- This interpretation has had many adherents, among them Edward Dent in Mozart's Operas, 1913, and the identification of Sarastro as von Born seems generally accepted, for example by Born's excellent biographer Edwin Zellwecker, 1953, despite the entire lack of evidence.

If we look at the libretto in its literary and stage contexts, it is first of all a fairy-tale -- though in an age that expected of its fairy-tales either some higher seriousness or some practical wisdom. The tests and trials of fairy-tale heroes out to win brides have been replaced with those of an initiation-theme, which heightens the mystery and solemnity of the transaction in a manner well suited to the tastes of the age, which was fascinated with such subjects, and would particularly impress members of the audience who happened to be Masons.

Further, the opera's theme of a conflict between light and darkness, suggesting the principles of Englightenment on the one hand and superstition and other forms of obscurantism on the other, is common to the liberal rhetoric of the day, both inside and outside of the lodges. From the mid-century the sun is widely used to symbolize Reason; while it was Louis XIV who made it a familiar symbol for his own royal absolutism, a century later many would speak of the fall of the Bastille as a new dawn heralding the dispersal of night. Closer to the progressive but far from revolutionary spirit underlying the Magic Flute, here are some lines from a letter von Born wrote to an absent brother in 1784: "We are still working according to our original plan. One gifted young man after another joins our circle; to achieve unity among the clear-thinking heads and good writers of Vienna is still our aim, and our work the spreading of the Enlightenment ... Who can estimate the good that such a coming-together of thinkers must necessarily produce, where so many well-prepared men and youths, eager for light, need only a ray to help them find for themselves the way out of the regions of superstition and intellectual slavery?"5

In Vienna in the 80s the majority of active progressives were Masons, though as we'll see by no means all Masons were progressives. Among those who were, apart from the intellectuals from the university and the civil service, many were writers or connected with the book trade, and a further large contingent came from the theatre and from other branches of the arts -- men with nothing behind them but their 
talents, all too familiar with the unreliability of the favour of the great, and enjoying in the lodges as nowhere else equality with fellow-citizens and respect as contributors to local and national culture.

Mozart was from late 1784 until his death a committed Mason; we know this less from his letters, evidently pruned by his family after his death, than from the records of lodge attendance and the several musical works he composed for special events in the lodge, clearly for love, not money. Schikaneder joined a lodge in Regensburg when he was running a theatre there in 1788 , but after a few months was suspended from membership, because of both non-attendance at meetings and some scandal about actresses in his company; there is not satisfactory evidence that he ever belonged to a lodge again, though some that Mozart may have taken him to his own as a guest; ${ }^{6}$ he may well have joined as many still do, just to make business contacts. I suspect it's because Schikaneder was so unexemplary a Mason that writers have latched onto the bit of late gossip that makes his employee Giesecke at least a co-author: Giesecke's undisputed stage writings are a lot feebler than Schikaneder's, but his record as a Mason is a lot steadier. I assume that Mozart, who always took an active interest in his librettos, was the one who pressed the Masonic theme.

Schikaneder was primarily a theater manager, concerned to satisfy his public; while the man who commissioned both The Magic Flute and Fidelio was hardly a total Philistine, he certainly never imagined he was writing for the ages to come: he was used to cobbling texts together fast out of whatever lay to hand, and famous above all for the splendour of his stage effects, which the texts existed to support. He once wrote: "I don't write for readers, I write for the stage ... my one idea is to work for the box-office and see what has the greatest theatrical effect in order to fill the seats and bring in a good return".

However, Schikaneder's other published texts, as well as what we know of a lost love-tragedy like Kabale und Liebe attacking the rigidity of class distinctions that had moved Joseph to invite him to Vienna in 1784 and give him a theatre, make it clear that he supported the Enlightenment semi-democratic ethos that characterized also the progressive part of Freemasonry -- a movement that was never homogeneous. For many brothers the lodge was essentially a social club whose best occasions were its dinners. For another kind of Mason it was the place where he might eventually, after long seeking and austerity, learn the secrets of conjuring spirits, prolonging life, or especially making gold; or, more practically, he might enrich himself by promising other brothers to impart those things. Or, especially if he was a member of Born's True Concord in its short life during the 80s, 
he might consider himself -- wrongly, as it turned out -- an unacknowledged friend and supporter of the great Joseph, working for the social and intellectual goals of Enlightenment, looking to the future as the monks whom Joseph had sent packing in thousands had looked to the past.

The Magic Flute's liberal note is most emphatically sounded in the opening scene of Act Two, where Sarastro and the brethren deliberate about admitting Tamino to the tests and ordeals leading to initiation: when the assembly declares him worthy, Sarastro thanks them in the name of "Menschheit", humanity -- the Speaker is to instruct him in the duty of humanity -- and when Sarastro is reminded about the risk that he may not survive the struggle -- after all he is a prince -- Sarastro replies, "Yet more -- he is a man!" In Scene 21, preliminary to the ordeal by fire and water that climaxes the tests, Sarastro congratulates Tamino on his progress so far and continues, "If your heart still beats as warmly for Pamina -- and if you want one day to reign as a wise Prince, then may the gods accompany you further" -- which suggests that we should see Tamino as one of those princes of 18th-century didactic fable who travel and/or seek a mystical initiation in order to fit themselves for later rule, in the tradition of Fénelon's Télémaque, 1699, which incidentally Schikaneder turned into an opera in 1795: this is a definitely Enlightenment theme in its requirement that rulers should fit themselves to rule justly and wisely.

Also typical of the time is the episode where Sarastro orders Monostatos punished for his tyranny: where there is injustice in high places, Enlightenment writers like to show that some official is responsible whom the ruler will punish once he finds him out -- as in at least one other Schikaneder text and again in Fidelio.

As for Ignaz von Born, it would be hard to come away from any study of Viennese Freemasonry without becoming deeply impressed by his abilities and by his character. Born came from a minor Hungarian noble family: he was a travelled and highly-educated man, who before being appointed by Maria Theresia to head her department of mines and coinage had as a private scholar with small resources been the prime mover in Prague of a scientific society. He had encouraged the regular publication of scientific papers and organized perhaps the world's first international scientific congress. In the five years he was master of True Concord, he built up a library for it, gave it his extensive collection of scientific specimens, ran a scientific journal from the lodge and encouraged a Masonic one, recruited new members among Vienna's best and brightest young men, worked indefatigably to advance their careers, and gave proof to intimates and visitors alike of 
not only a remarkable gift for friendship but also princely generosity on a rather mean Josephine civil-service salary. All this with carrying on his official career with distinction, on a background of a wretched marriage to a hostile and somewhat crazy wife (Georg Forster called her Lady Macbeth) and bouts of intense pain with less and less use of his legs, owing to a heavy dose of lead-poisoning early in life, when he was overwhelmed with vapour from a metallurgical operation in a Hungarian mine -- a martyr to scientific enquiry, as he sometimes remarked.

As a champion of Enlightenment values during Joseph's reign and a man of outstanding intellectual and spiritual power, Born might seem, to someone set on making such identifications, a reasonable candidate for the real-life original of Sarastro. Moreover, while Schikaneder probably didn't know him personally, Mozart did, and had composed a short cantata in his honour; and Mozart's lodge Beneficence, more modest in its ambitions and correspondingly in its membership fees than True Concord, shared True Concord's premises and also some of its rites and festive days.

Born died at the end of August in that very busy summer of 1791 when Mozart was working himself into his final illness with the composition of not only The Magic Flute but also the Requiem and La Clemenza di Tito which he went to Prague to direct (and where in Born's old lodge he was greeted with his own Born cantata, "Maurerfreude"). It's conceivable, though not probable, that Mozart had spent, or sent his friend Schikaneder to spend, time thrashing the opera plan out with the now thoroughly crippled Born, about to die a sad and ruined man, four years after walking out on Freemasonry and all its works for reasons we'll come to.

Sarastro's greatest moment comes in the second act with the singing of his aria, "In diesen heil'gen Hallen/Kennt man die Rache nicht". If the image of Born had crossed the mind of a Viennese audience at that point, I'm afraid they might have dissolved in disrespectful laughter, as Born with all his virtues was not free from vengefulness. He joined gleefully in Joseph's campaign against the religious orders, being universally hailed as the author of a widely-circulating anonymous satire on monasticism of 1783; when Vienna's leading churchman Cardinal Migazzi went to Joseph and demanded its suppression, Born, not satisfied with Joseph's refusing to reply, pulled some strings and got a small honorarium that the avaricious Cardinal received every year for his Lenten sermons diverted to charitable purposes. Again, when a young man named Kratter reported in unfriendly fashion in an anonymous pamphlet on some of the proceedings of Born and his party 
in Masonic politics, Born after getting the author identified invited him personally, with smiling face, to a Masonic dinner where he then stood up and denounced him, and Kratter felt himself lucky to escape from the house without being manhandled. The episode is very uncharacteristic of Born, a man usually of most upright conduct; but it happened, and was widely publicized through a second pamphlet by the victim, dwelling on the acknowledged duty of Masons to reclaim an erring brother by kindness -- just the subject of the aria.

A further matter concerning Born. The real downfall of Viennese Freemasonry came a few years before the decade of reaction and repression that followed the fall of the Bastille; it came when Kaiser Joseph at the end of 1785 published an edict bringing the Austrian lodges under close police supervision and requiring the national executive to radically cut down both their number and the size of their membership. Various reasons have been offered for Joseph's willingness to draw up the edict, which he did himself in his characteristic blunt prose; but it was believed from the beginning, and seems to be the fact, that the instigator of the edict, and the one who planned how it should be carried out, ostensibly by the National President of the Austrian Grand Lodge, was actually the National Secretary, von Born. (This move and its aftermath is the subject of Kratter's first pamphlet.) In the course of what was in effect a purge, the eight Viennese lodges were reduced to two and the membership was cut, or cut itself by indignant resignations, to little more than half what it had been -- Mozart stayed in till his death, but the surviving lodges were ridden with cliques and dissensions, and many more brothers left over the next months, including Born himself and his supporters.

In urging Joseph to draw up the edict, Born probably had three kinds of consideration in mind. First, Joseph nursed a variety of suspicions about the lodges, from their giving opportunities to charlatans and swindlers to their providing meeting-places for Hungarian malcontents and if he weren't satisfied he might well close them down altogether, as Migazzi and other churchmen kept pressing him to do. Second, Rosicrucianism and related occult activities had infiltrated all of the lodges including his own: apart from the taint of criminality attaching to these, Born as a man of science detested such dabbling in magic: further, occult mystery-mongering inside the lodges was one of the two faces of the Counter-Enlightenment, religious obscurantism outside them being the other, and links between the two often being suspected. (By the way, while I don't see The Magic Flute as any kind of allegory, or Schikaneder and especially not Mozart as people with political axes to grind, I would find a Queen of the Night involved with 
occult hocus-pocus more convincing than one resembling the late Empress and surrounded with priests, as in the Miller production; it would fit her fairy-tale witchlike character, and further, with censorship reinstated over a year before and the secret police turning more and more from surveillance of the civil service and the military to spying on ordinary citizens, it would be a much less tendentious topic to hint at. Maria Theresia after all was the mother not only of the generallypopular Joseph but also of his newly-crowned successor Leopold II: her imprisoned daughter would inevitably raise thoughts of their sister Marie Antoinette.) Third, a more complicated matter behind Born's purge of the lodges: if these were influenced from the right wing by Rosicrucians and other dabblers in magic, so they were from the left by the Illuminati, a body that had managed to make some distinguished converts, Born himself among them, before repression in its native Bavaria in 1785-6 both dissolved the Order and brought to light some very sinister-looking correspondence among its local top brass. The strongest Austrian cell of the Illuminati was that in True Concord, directed by Born and another great man, the jurist Joseph Sonnenfels. It appears that Born's purge of the occultists was a stroke designed to prepare the way for the development of Viennese Masonry along unequivocally Illuminatist lines. And further, the Bavarian hierarchy was now in disarray, its leaders in flight or imprisoned: did Born perhaps see Vienna as the new Illuminati centre, with Freemasonry under Joseph's protection taking on more and more the image of an academy of practical wisdom, shaping characters and training skills that in turn went out and reshaped social structures in the light of freedom and equality? And believe that such a goal justified a little shortterm despotism? Whatever his intentions, it was this action of Born's, rather than Joseph's suspicions or the enmity of the official Church, that knocked the heart out of Austrian Freemasonry, which he had done so much to reform and inspire, some years before its end.

It is for these various reasons that I think 1791 a little soon to present Ignaz von Born on a Viennese public stage as the idealized Master of a Masonic lodge.

JAY MACPHERSON

Victoria College, University of Toronto 


\section{NOTES}

1. In an article by Emil Karl Blümml on early criticism of the Flute, Mozart Jahrbuch 1923, on which I have drawn very heavily for the first half of this paper

2. Revived Jan.-Feb. 1986 by the English National Opera. -- A fellow member of the CSECS conference, Dr. Catherine Kerrigan, Edinburgh, has informed me that the production was heavily subsidized by the very left-wing town council of Glasgow; under these circumstances, and with a Glasgow audience in mind, this choice of interpretation may have been an inspired one.

3. G.F. Rebmann, Die Wächter der Burg Zion, 1796, pp. 8-10, quoted in Klaus Epstein, The Genesis of German Conservatism (Princeton: Princeton Univ. Pr., 1966), p. 532.

4. The publisher and engraver, Ignaz Alberti, was a member of True Concord and produced other more directly Masonic works, such as the lodge oration on Mozart's death; in the lodge painting mentioned in $n .6$ below, his is one of the most easily identifiable portraits.

5. Born's letter of 9.vi.84 to Karl Reinhold, from Wiener Freunde, ed. Robert Keil (Vienne: Konegen, 1883), p. 35.

6. In an anonymous group painting belonging to the Historisches Museum der Stadt Wien, H.C. Robbins Landon has convincingly identified Mozart and Schikaneder seated side by side; he dates the painting to early 1790 . See his Mozart and the Masons: new light on the lodge, 'Crowned Hope' (London: Thames \& Hudson, 1982), pp. 52-6. Further, Schikaneder is said to have supplied the words for Mozart's last composition, the "Little Masonic Cantata", K. 623, of November 1791.

7. Egon Komorzynski, Der Vater der Zauberflöte: Emanuel Schickaneders Leben (Vienna: Neff, 1948), p. 108. 